\title{
Die ontwikkeling van 'n inasemingsmiddel uit wildegemmer (Siphonochilus aethiopicus) vir die behandeling van 'n Influensa A-virus
}

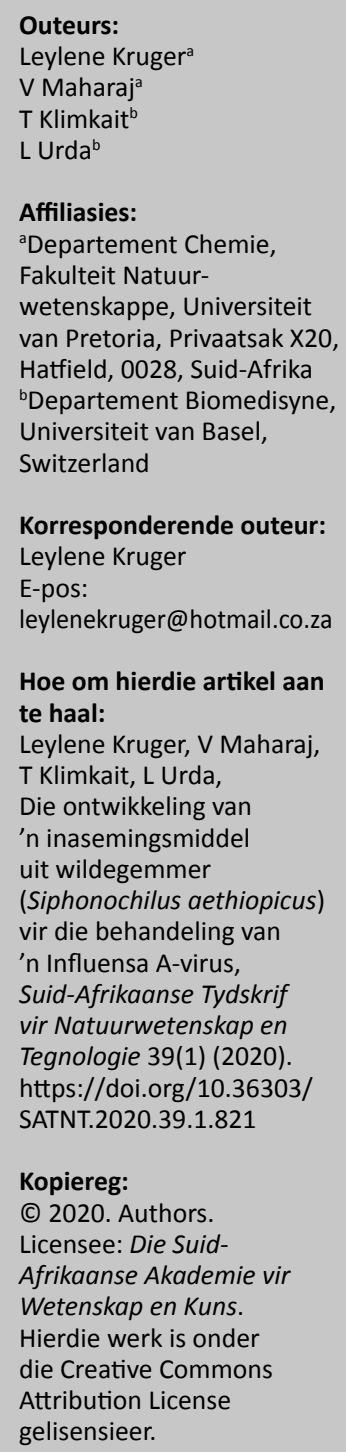

Korresponderende outeur: Leylene Kruger

\begin{abstract}
The development of an inhalant from African ginger (Siphonochilus aethiopicus) for the treatment of an Influenza A virus: One of the traditional uses of African ginger is against the influenza virus. The antiviral activity of essential oil and pure compounds from the rhizomes of African ginger against the Influenza A virus was tested and it was found that the major compound, siphonochilone, and its lactone has outstanding antiviral activity.
\end{abstract}

Griep is 'n ernstige, wêreldwye gesondheidsprobleem met een biljoen gevalle en tussen 290000 en 650000 sterftes jaarliks (World Health Organization 2019). As dit nie betyds behandel word nie, kan dit tot bakteriële longontsteking, sinusinfeksies en verergering van asma, diabetes en kardiovaskulêre siektes lei, wat uiteindelik die dood kan veroorsaak (Rothberg et al., 2008). Die voortdurende verandering van virusse en hul ontwikkeling van weerstand teen geneesmiddels bemoeilik die bekamping van die siekte wat die behoefte aan nuwe, natuurlike griepmedisyne beklemtoon.

Een van die mees gebruikte medisinale plante in Suid-Afrika is wildegemmer (Siphonochilus aethiopicus). Dit word tradisioneel gebruik vir die behandeling van asma, verkoue, griep en sinusprobleme (Holzapfel et al., 2002). Min navorsing is al gedoen om die effektiewe aksie teen die griepvirus vas te stel, ten spyte van die tradisionele gebruik van die risome en wortels, vir die behandeling daarvan.

Die antivirale eienskappe van die essensiële olie en twee suiwer verbindings van wildegemmer teen die Influensa A-virus (108 617) is ondersoek, met die doel om 'n plantgebaseerde inasemingsmiddel vir kommersiële doeleindes te produseer.

Die essensiële olie van die risome is deur stoomdistillasie geproduseer, terwyl die hoofverbinding, siphonochilone, tydens hierdie proses uitkristalliseer. Die siphonchilonelaktoon, 'n geoksideerde vorm van die verbinding, is deur middel van silikagel-kolomchromatografie geïsoleer (Zongwe et al., 2018). Al drie monsters is onderskeidelik getoets vir antivirale eienskappe deur die verdunde essensiële olie $(0,05-50 \mu \mathrm{g} / \mathrm{ml})$, siphonochilone en sy laktoon $(3,75-50 \mu \mathrm{g} / \mathrm{ml})$ by besmette MDCK-selle te voeg en dan vir drie dae by $37^{\circ} \mathrm{C}$ in $5 \%$ $\mathrm{CO}_{2}$ te inkubeer.

'n Bekende antivirale middel, ribavirin, is as kontrole gebruik. Die essensiële olie het geen tot minimale aktiwiteit $(<35 \%$ inhibasie by $50 \mu \mathrm{g} / \mathrm{ml})$ teen die Influensa A-virus getoon. Siphonochilone het dosis-verwante aktiwiteit getoon met $>115 \%$ en $>13 \%$ inhibisie by onderskeidelik 50 en $5 \mu \mathrm{g} / \mathrm{ml}$. Die laktoon het uitstekende antivirale eienskappe getoon met $>123 \%$ inhibasie by $50 \mu \mathrm{g} / \mathrm{ml}$, en $>30 \%$ inhibasie by $5 \mu \mathrm{g} / \mathrm{ml}$. Beide het redelik goed vergelyk met die positiewe kontrole, ribavirin, wat $>105 \%$ inhibisie by $50 \mu \mathrm{g} / \mathrm{ml}$ toon. Beide siphonochilone en sy laktoon het geen sitotoksisiteit getoon nie. Gesamentlik lewer die data wesenlike bewyse vir die voortgesette ondersoek om natuurlike produkte te gebruik vir die soeke na nuwe antivirale griepmedisyne.

\section{Verwysings}

Holzapfel CW, Marais W, Wessels PL, Van Wyk BE. 2002. Furanoterpenoids from Siphonochilus aethiopicus. Phytochemistry 59(4), 405-407.

Rothberg MB, Haessler SD, Brown RB. 2008. Complications of viral influenza. The American Journal of Medicine 121(4), $258-264$. World Health Organization. 2019. WHO launches new global influenza strategy. https://www.who.int/news-room/detail/11-032019-who-launches-new-global-influenza-strategy (Geraadpleeg op 4 September 2019).

Zongwe FK, Muya JT, Mutimana R, et al. 2018. Autoxidation of Siphonochilone in processed rhizomes and stored powders of Siphonochilus aethiopicus (Schweinf.) BL Burtt. ChemistrySelect 3(30), 8569-8574.

Nota: 'n Seleksie van referaatopsommings: Studentesimposium in die Natuurwetenskappe, 31 Oktober - 1 November 2019, Universiteit van die Vrystaat. Reëlingskomitee: Prof Rudi Pretorius (Departement Geografie, Universiteit van Suid-Afrika); Dr Hertzog Bisset (Suid-Afrikaanse Kernenergie-korporasie; Dr Ernie Langner (Departement Chemie, Universiteit van die Vrystaat) en Dr Wynand Nel (Departement Rekenaarwetenskap en Informatika, Universiteit van die Vrystaat). 